\title{
Anmeldelser
}

Peter Gundelach (red.), Danskemes vardier 1981-1999, København: Hans Reitzels Forlag, 2002, 308 s., kr. 250,00.

Bogen er seneste publikation fra de undersøgelser, som i 1980'erne og 1990'erne har kortlagt befolkningernes værdier i en række europæiske lande. Den analyserer danske data og sammenligner udviklingen i perioden fra 1981 over 1990 til 1999, hvor unders $\emptyset$ gelserne er gennemført i Danmark. Bogen repræsenterer en mangfoldighed af analyser, der alle relaterer sig til danskernes værdier. Områder som politik, familieværdier og arbejdsværdier behandles grundigt. Analyserne viser blandt andet, at kernefamilien tillægges stadigt større betydning, tilliden til den danske folkekirke er stigende, og religion opleves af befolkningen i højere grad som en åndelig og personlig søgen. Desuden er stoltheden over at være dansk stigende.

For en helt overordnet betragtning er bogens hovedkonklusion, at danskernes værdier stort set ikke har ændret sig i den 20 års periode, undersøgelserne strækker sig over. Gundelach tager dog et vist forbehold og påpeger, at almene og brede teorier er vanskelige at teste i en surveyundersøgelse med en - trods alt - begrænset undersøgelsesperiode på 20 år (p. 46). Den generelle og centrale forventning er, at udviklingen fra et moderne til et postmoderne samfund påvirker individernes oplevede tilhør til samfundets institutioner. Desuden forventes det, at det postmoderne samfunds individer bliver stadigt mere refleksive, og at værdierne derfor generelt bliver mere heterogene. Med dette som udgangspunktet opstiller Gundelach tre hypoteser.

Første hypotese er, at samfundets institutioner kommer til at betyde mindre for befolkningen. Resultaterne går imidlertid $\mathrm{i}$ en anden retning end det forventede. Danskernes holdninger til nationalstaten er ganske vist for nedadgående, men følelsen af tilknytning til det lokale er klart stigende. Desuden vises, at folkekirken i stigende grad opleves som en institution, der udfylder menneskers åndelige behov. Kun danskernes holdninger til det offentlige er mere tøvende, men ændringerne er små, og tilliden ligger stadig generelt højt.

Den anden hypotese er, at værdier tæt knyttet til uddannelse bliver stadigt vigtigere. Hypotesen bygger på argumentet om, at stigende uddannelsesniveau fører til højere grad af refleksivitet i befolkningen. Som første indikator på refleksivitet ser Gundelach på, hvilke elementer, folk betoner i børneopdragelsen. Det vises, at betydningen af egenskaber som selvstændighed og tolerance/respekt er steget gennem unders $\varnothing$ gelsesperioden, hvilket siges at pege i retning af en $\emptyset$ get prioritering af refleksive elementer og dermed støtte til hypotesen. Anden indikator på refleksivitet knytter sig til autoritet, og på baggrund af et spørgsmål om svarpersonemes villighed til at følge arbejdsinstrukser trods uenighed i disse, viser analyserne et markant fald i andelen, som mener, at man i sådanne tilfælde uden videre skulle følge instrukserne. Ovenstående to forhold tager Gundelach til indtægt for en positiv udvikling i danskernes refleksivitet, jf. hypotesen. Han forholder sig dog selv- 
kritisk til kvaliteten af disse analyser og skriver, at "der kun er meget primitive muligheder i spørgeskemaerne for at vurdere om der sker en udvikling i retning af mere refleksivitet" (p. 60).

Tredje hypotese hævder, at værdierne med overgangen til det postmoderne samfund til stadighed bliver mere fragmenterede. Hypotesen testes ved at analysere en række spørgsmål inden for sfærer som religion, moral, familie, politik og arbejde. Resultaterne af analyserne tegner et yderst broget billede, og konklusionen er alt andet end entydig. Gundelach siger selv, at "hypotesen om værdifragmentering er vanskelig at vurdere, fordi værdifragmentering er svær at måle" (p. 74).

Et generelt problem ved analyserne af de tre ovenstående hypoteser er, at datamaterialet kun i meget begrænset omfang belyser delelementerne i hypoteserne. Mere præcist er problemet, at brede hypoteser ofte testes på baggrund af blot ét enkelt spørgsmål. Dette forhold stiller enorme krav til indholdsvaliditeten i spørgsmålsformuleringerne - faktisk synes kravene så høje, at det næsten virker umuligt at opfylde dem. Anlægger man derudover en dimensionstankegang, er det (retorisk) indlysende, at kun det helt overordnede billede af de analyserende områder kan tegnes. Spørgeskemaet giver således ikke mulighed for test af eventuelle dimensioner i danskernes værdier i relation til ovenstående hypoteser. Kritikken skal naturligvis ses i lyset af, at forfatternes indflydelse på undersøgelsens spørgsmålsformuleringer formodentlig har været begrænset.

Alle bogens analyser er - så vidt det har været muligt - bygget på samme fælles skabelon, den såkaldte DIGRAM-analyse. Metoden behandler alle målinger ordinalt, og analyserne er bygget op omkring sammenhængemålet gamma. Desuden inddrages kontrol for tredjevariable i udstrakt grad i analyserne.

Med valget af DIGRAM-metoden lægger bogen således klar afstand til det brede spekter af metoder, som er udviklet til surveydata. Som samfundsforsker står det naturligvis altid en frit for at vælge de metoder, der findes bedst egnede til formålet. Men i relation til analyserne af danskernes værdier synes metodevalget ikke uproblematisk. Fordelene ved DIGRAM-analysen er klare: ensartede analyser, der $\emptyset$ ger læseværdigheden betydeligt. Om dette forhold skriver Gundelach selv, at bogens homogenitet er "fors $\emptyset \mathrm{gt}$ etableret gennem den statistiske teknik som udarbejdet" (p. 9). Ulemperne er desværre lige så klare: Med sin afstandtagen til "klassiske surveymetoder" fraskriver forfatterne sig muligheden for dyberegående analyser samt egentlig modelopbygning. Ærgerligt, når man tænker på den mangfoldighed og rigdom, dataene repræsenterer!

Ser vi på de data, som er indsamlet i 1999, springer to problemer umiddelbart $\mathrm{i}$ $\emptyset$ jnene. For det første er de grundet indsamlingsproblemer fremkommet over en længere periode, end det umiddelbart synes hensigtsmæssigt. For det andet lider de indsamlede data af, at en meget stor del af respondenterne har nægtet at deltaget $\mathrm{i}$ unders $\varnothing$ gelsen. Problemet med selvselektion kommer til udtryk ved, at $29 \mathrm{pct}$. af bruttostikprøven udgøres af interviewpersoner, som ikke har ønsket at deltage i undersøgelsen (p. 301). De to ovenstående forhold rejser et generelt spørgsmål omkring validiteten af de indsamlede data! Gundelach formoder ikke, at dette har konsekvenser for analyseresultaterme, hvorfor data ikke er vejet (p. 302). Baggrunden for denne formodning fremstår meget svagt. 
Et bemærkelsesværdigt forhold, undersøgelsernes omfang taget i betragtning, er, at formålet med unders $\emptyset$ gelsen aldrig har været udførligt klarlagt. Således hedder det $\mathrm{i}$ bogen blandt andet: "Motivation og baggrund for oprettelsen af gruppen er aldrig blevet udførligt beskrevet" (p. 18). Gundelach skriver senere, at "den største ulempe er at den internationale unders $\emptyset$ gelse overordnet set ikke er tilrettelagt ud fra særligt præcise teoretiske udgangspunkter" (p. 40). Det må naturligt vække en del undren, at forfatterne fra starten direkte vælger at fraskrive sig selv mulighederne for at anvende metodiske teknikker af mere eksplorativ karakter specielt når undersøgelsesoplægget (eller mangel på samme) holdes in mente.

Et af de ærgerlige forhold ved bogen er, at den ikke indtænker generelle samfundsmæssige ændringer i udviklingen i danskemes værdier. Gundelach er selv inde på problemstillingen og skriver: "men i denne bog må vi lade os nøje med mere overfladiske analyser, hvor de samfundsmæssige forhold i de sidste årtier beskrives i mere generelle termer" (p. 31). Pointen er således, at Gundelachs overordnede konklusion om, at danskernes værdier er stort set uændrede, $i$ virkeligheden kan tænkes at dække over noget yderst interessant. Med hvilken ret ville en samfundsforsker forvente, at danskemes værdier ville være uændrede i en omskiftelig periode på næsten 20 år? Måske er bogens overordnede konklusion om stabilitet i danskernes værdier i virkeligheden meget mere interessant end den umiddelbart lyder og fremstilles!

På trods af de påpegede metodiske problemer i undersøgelsen er mængden af interessante analyser og resultater uomtvistelig. Bogen indeholder et væld af analyser og kommer i dybden med en bred vifte af de problemstillinger, en gennemgribende analyse af danskemes værdier bør indeholde.

Kenneth Thue Nielsen Institut for Miljøvurdering

Erik Albæk, Peter Munk Christiansen og Birgit Møller (red.), Demokratisk set: Festskrift til Lise Togeby, Århus: Aarhus Universitetsforlag, 2002, 255 s., kr. 248,00.

Professor Lise Togeby, der står i spidsen for Magtudredningen, er fyldt 60 år. I den anledning er der udgivet det efterhånden også i statskundskab obligatoriske festskrift. Festskrifter er en særlig - og ærligt talt også noget tvivlsom - genre. Bidragyderne medvirker mere, fordi de vil give en fødselar en velfortjent hyldest, end fordi de har nogen fælles tematik. Bidragene stritter ofte i alle retninger. Artiklerne kan også være præget af det kuriøse og lidt skæve, som forfatterne ikke har haft mulighed for at publicere andre steder, eller fordi forfatterne ganske simpelt bare skulle ryste op med noget i en fart. Det gælder også det foreliggende festskrift, selv om det dog også skal med, at nogle af bidragene holdes til de temaer, som især har kendetegnet Lise Togebys eget, på mange måder imponerende forfatterskab. Men det løser ikke helt problemet; for også Togebys forfatterskab er nået vidt omlring gennem mange år. Det viser en glimrende lille oversigt over forfatterskabet, som redaktøreme har begået. 
Resultatet af forfatternes anstrengelser er sjældent bedre end summen af de 16 enkeltbidrag. Heldigvis er der en række interessante artikler. Pladsen tillader ikke, at jeg nævner alle. Men nævnes skal Asbjørn Sonne Nørgaards artikel om Socialdemokratiets velfærdspolitik 1890-1913, som behandler et tema, Togeby selv har behandlet under overskriften "Var de så røde?" Socialdemokraterne var ikke så røde, at det gjorde noget. De var heller ikke så afklarede og konsekvente, som man måske efterrationaliserende har gjort dem.

Palle Svenssons artikel fortjener at nævnes, fordi Svensson benytter lejligheden til noget så usædvanligt som at være kritisk over for festens genstand, Lise Togeby. Diskussionen går på, hvorvidt danskerne har (med)ansvar for, at indvandrerne udnytter deres demokratiske rettigheder. Svensson lægger mere end Togeby vægt på, at indvandrerne først bør integreres.

Peter Munk Christiansen og Birgit Møller skriver om en del af de, der i disse år befolker den danske "elite". Artiklen er en udløber af Magtudredningen. En stor del af eliten er som Togeby født under besættelsen som bedrestillede "mørkelægningsbørn". Blandt andet fremhæver artiklen, at de i modsætning til ældre elitegenerationer næsten ikke tager del i samfundets almennyttige organisationer. De kan kaldes "klassen, der nasser" eller "klassen, der passer ... sig selv", synes forfatterne, der vist næppe selv just er mørkelægningsbøm. Egentlig er der nu intet overraskende ved resultatet. For ingen generation er blevet flasket op med troen på offentlige løsninger og foragt for hattedamer end netop fyrtitalisterne. Men den manglende forpligtethed over for noget større end ens egen karriere lever videre hos også yngre generationer. Nok også blandt danske politologer. Indholdet er godt kronikstof. Man kan kun opfordre forfatterne til at skrive i aviser herom, så Magtudredningen kommer mere ud over rampen, end det hidtil er lykkedes.

Hans Jørgen Nielsen diskuterer, hvor ustabile de danske vælgere nu også er. Spørgsmålet har været diskuteret som vælgernes forhold til partierne et ad gangen. Nielsen peger på, at der er en vrimmel af partier i Danmark. Der er derfor den mulighed, at vælgerne ofte kan lide flere partier på samme tid. Nielsen hævder, at vælgerne ofte knytter sig til grupper af partier. Der er ikke den store forskel på nabo-partier. Hvis man ikke medtænker det, kan man komme til at overvurdere vælgernes troløshed. Synspunktet forekommer interessant og er en vigtig påmindelse om, at den tilsyneladende ustabilitet, vi har set siden især 1973, også kan rumme megen stabilitet - selv om Nielsen også erkender, at der er en del problemer med at påvise stabiliteten bag den tilsyneladende ustabilitet.

Jørgen Elklit skriver om, hvor vidt vælgerne stemte forskelligt den 20.11.2002, som var en enestående valgdag, fordi der samtidigt var valg til Folketing og kommuner. Foreløbige analyser tyder på, at ikke mindre end 33 pct. stemte forskelligt ved folketingsvalg og kommunalvalg. Artiklen er præget af, at den skulle skrives inden analysen var færdig.

Signild Vallgårda har en interessant analyse af folkesundhedsprogrammer i Danmark, Sverige og England. Næppe overraskende konkluderer hun, at programmerne i Sverige og England er præget af appeller til solidaritet med fællesskabet (S), respektive at man lægger vægt på den enkeltes valg og ansvar (UK). Det overraskende er nok, at den danske styring lægger mere vægt på autoritær styring 
gennem handlingsanvisninger, end tilfældet var i de to andre lande. Her ender analysen desværre.

Erik Albæk har en lille perle af en analyse af dansk rygepolitik. Artiklen oser ikke af røg, men af noget så sjældent som humor i dansk statskundskab. En række af de traditionelle virkemidler såsom høje punktafgifter og forbud mod reklame i tv og radio har så godt som ingen effekt. Det paradoksale er, at det synes at have større effekt på aktive rygere, at der gøres tiltag for at hindre passiv rygning, fordi disse er med til at gøre rygning odiøs. Til gengald rejser artiklen tvivl, om passiv rygning overhovedet i sig selv er et større problem. Spørgsmålet bliver derfor, om det er legitimt, moralistisk og fordømmende at ville bremse den passive rygning for i virkeligheden at stigmatisere de aktive rygere? Det sætter forfatteren stort spørgsmålstegn ved.

Torben Beck Jørgensen giver en ikke mindst takket være Brian Mikkelsen interessant analyse af problememe for det repræsentative demokrati med at styre kulturorgansiationer. Det konstateres blandt andet, at kontraktstyring er ganske udbredt på kulturområdet. Det kan ifølge forfatteren ikke afvises, at denne form for dialogpræget styring giver mulighed for, at faglig uafhængighed kan sameksistere med bureaukratisk kontrol. Og det er heldigt: For frie, grænseprøvende kulturinstitutioner bidrager til ytringsfriheden.

Jørgen Goul Andersen skriver om medborgerskab og politisk deltagelse. Artiklen er en kenders diskussion af forskellige tilgange til spørgsmålet om medborgerskab. Løsrevet fra empiri har artiklen nok mest interesse for nogle få specialister. En del af de behandlede problemer skyldes nok, at man ofte i nordisk sammenhæng tager udgangspunkt $\mathrm{i}$ angelsaksiske teorier og begreber.

Med al respekt for Erik Damgaards noget andedamsagtige tilbageblik på et tilløb til en lille dansk magtudredning for næsten et kvart århundrede siden, så virker det lidt underligt placeret mellem tre meget vægtige bidrag om ganske vist tre vidt forskellige emner. Ingen af de tre vægtige bidrag bliver dog til andet end vigtige betragtninger, som man geme havde set videreudviklet. Det gælder Olof Petersons forsinkede og bagkloge tanker om, hvad den svenske magtudredning egentlig burde have handlet om. De kan også ses som et bud på, hvordan den danske magtudredning burde have været. Den skulle have haft et konstruktivt konstitutionelt sigte. Undertegnede finder, at det er en indlysende rigtig tanke - som kommer lige akkurat nogle postgange for sent. Lad os huske den til næste gang!

Mogens N. Petersens lidt causerende bidrag om deliberation og forhandling har nogle meget vægtige påmindelser om, at den lille og dog så vigtige debat mellem Koch og Ross nåede meget langt. Tilmed $\mathrm{i}$ et mere letlæseligt sprog end det, mange modeme politologer betjener sig af.

At vi ikke skal opgive de gamle tænkere og de klassiske debatemner minder også Curt Sørensens fortolkning af Marx' klasseanalyse om. Man kunne måske tvivle på, at det i dag kan lade sig gøre at skrive friskt og interessant om Marx, men artiklen viser, at det kan man. Denne læser havde geme læst mere - og frem for alt havde jeg geme set tankeme fors $\emptyset \mathrm{gt}$ anvendt i empirisk forskning.

Bogen er en blandet landhandel. Nogle af de mere præliminære bidrag er interessante og tankevækkende oplæg til forfattemes egen videre forskningsdagsorden. 
De offentliggøres i en tid, hvor blandt andet Magtudredningen sørger for en flodbølge af nye publikationer, som dagbladene kun i meget ringe omfang orker at anmelde. De offentliggøres også i en tid, hvor politikere, ministerium, Dansk Industri og journalister kræver dokumentation for forskningsindsats. Men resultatet af for let at give efter for dette publiceringspres kan blive, at vi får et stadig større overskuelighedsproblem, og at der samlet set læses mindre. Spørgsmålet for denne anmelder er, om ikke vi alle - og bestemt ikke alene bidragsyderne til denne publikation - snart skal være lidt mere disciplinerede med, hvad og hvor vi publicerer. For eksempel skulle vi måske overveje, om ikke vi kan skrive festskrifter på en anden måde. I nogle tilfælde kunne det være bedre for interessen for dansk samfundsforskning, hvis man genudgav nogle af fødselarens vigtigste arbejder. Denne bemærkning ændrer dog ikke ved, at der er adskillige læseværdige og også ganske underholdende bidrag i bogen. $\mathrm{Og}$ måske er vi tilfredse med at skrive for hinanden og se det som et udtryk for provinsialisme, hvis nogen også tænker på at skrive for det danske samfund?

Tim Knudsen

Institut for Statskundskab

Københavns Universitet

Bernt Aardal (red.), Valgdeltakelse og lokaldemokrati, Oslo: Kommuneforlaget, 2002, 273 s., Nkr. 390,00.

Valgdeltakelse og lokaldemokrati fra Lokalvalgprojektet er et af de seneste bidrag til afdækning af den dalende deltagelse ved kommunalvalgene i Norge. Om end bogen hovedsagelig er rettet mod norske forhold, og vi i Danmark endnu kan bryste os af stabil deltagelse ved både folketings- og lokalvalg, har den alligevel interesse. En sådan interesse skal ikke knyttes til det synspunkt, at lav valgdeltagelse er et demokratisk problem, men til det forhold, at ændringer i befolkningens politiske deltagelse altid bør have interesse i statsvidenskaben.

Bogen er hovedsagelig koncentreret om valgdeltagelse, og spørgsmålene "Hvorfor synker valgdeltakelsen? Hvorfor er den lavest blant de nordiske land?" (p. 11) er centrale. I bogens seks første kapitler er valgdeltagelse omdrejningspunktet. I kapitel 1 gives en oversigt over udviklingen i valgdeltagelsen og teorier om valgdeltagelse (Bernt Aardal). Unders $\emptyset$ gelse af forskellige forklaringsmodeller er gennemgående i de følgende kapitler. I kapitel 2 anvendes aggregerede data til at teste tre forklaringsmodeller: Et politisk perspektiv, et liberalistisk og et kommunitært (Tore Hansen, Ingunn Opheim Ellis og Anne Lise Fimreite). I kapitel 3 unders $\varnothing$ ges forklaringsmodeller på individniveau, og konsekvenser af den lave deltagelse diskuteres (Tor Bjørklund). Forklaringsmodeller på nationalt, kommune og individniveau afprøves i kapitel 4, som er en sammenligning af valgdeltagelsen ved kommunalvalg i Danmark og Norge (Tor Bjørklund og Ulrik Kjær). Kapitel 5 har ligeledes et nordisk perspektiv og inddrager foruden Norge og Danmark også Sverige og Finland. Analyseniveauet er blot individniveau og bygger på interview- 
spørgsmål, der er stillet i alle fire lande (Per Stava). Afprøvningen af forklaringsmodellerne rundes af i kapitel 6 med en analyse af, i hvilket omfang de norske vælgere opfatter det som en borgerpligt at stemme samt sammenhængen mellem en sådan opfattelse og valgdeltagelse (Lawrence Rose).

De øvrige fem kapitler har lidt andre tilgange til lokaldemokratiet. Kapitel 7 ser på vælgernes villighed til at påtage sig kommunale hverv og deres holdninger til lokalpolitikkens partipolitisering (Jo Saglie). Lokale folkeafstemninger, deres temaer, omfang og deltagelse er emnet i efterfølgende kapitel (Aimée Lind Adamiak). Herefter følger to kapitler, som evaluerer to forsøg, der bl.a. har haft til formål at motivere vælgerne til at finde hen til stemmeurnerne. I kapitel 9 beskrives et forsøg med direkte valg af ordfører, som blev gennemført i 20 mindre kommuner, mens kapitel 10 ser på bydelsvalgene i Oslo, valgdeltagelsen ved disse samt vælgernes opfattelse af bydelsrådene. Bogen runder i kapitel 11 af med en beskrivelse og analyse af indvandrernes valgdeltagelse (Tor Bjørklund og Karl-Eirik Kval).

Bogen rummer mange interessante analyser og diskussioner af teorier og perspektiver og udgør et vigtigt bidrag til belysning af lokale valg. Den har dog også en række svagheder. Her vil jeg koncentrere mig om det, jeg opfatter som bogens mission, nemlig forsøgene på at forklare valgdeltagelsen.

Jeg synes, at det mest ærgerlige ved bogen er, at designet for flere af analyserne medfører, at forfatterne ikke kan svare på et af de centrale spørgsmål: Hvorfor falder valgdeltagelsen? Dette spørgsmål lægger op til, at den afhængige variabel (valgdeltagelsen) er dynamisk (ændring i valgdeltagelse). Det er i mange af analyserne ikke tilfældet. Det skyldes for det første, at en stor del af datamaterialet til bogen stammer fra surveys foretaget omkring lokalvalget i 1999, og hvor det for væsentlige spørgsmål ikke er muligt at sammenligne tilbage i tid. Man kan således godt vise, at en norm om, at det er en borgerpligt at stemme, er vigtig for, hvorvidt vælgeren stemmer eller ej, men man har ikke dermed påvist, at den faldende valgdeltagelse skyldes en svækkelse af denne norm (kapitel 3 og 6). For det andet udnyttes muligheden for at studere ændringer i valgdeltagelse ikke der, hvor den faktisk er til stede. Som nævnt rummer kapitel 2 en analyse på basis af aggregerede data. Det er imidlertid variationen i valgdeltagelsen mellem kommunerne, der forsøges forklaret. Det er naturligvis også interessant. Men sådanne analyser vil ofte afdække traditionelle skillelinier, der altid har gjort sig gældende. Og analysen fortæller intet om, hvad der kendetegner de kommuner, hvor valgdeltagelsen falder, hvilket kunne have været yderst interessant.

Kun i kapitel 3 (Bjørklund) og kapitel 4 (Bjørklund og Kjær) er der enkelte analyser, som ser på valgdeltagelse over tid. I begge tilfælde er der tale om en indkredsning af problemet. Bjørklund viser dels, at tilbagegangen i valgdeltagelsen er størst i de store kommuner dels, at valgdeltagelsen er faldet mest blandt de unge. I kapital 4 vises, at netop med hensyn til disse to forhold adskiller Danmark og Norge sig. I Danmark har deltagelsen blandt de unge samt i de mellemstore og store kommuner tilsyneladende været stabil. Indkredsningen af problemet er yderst interessant, fordi det netop er forudsætningen for at identificere mulige forklaringer på den faldende deltagelse. Men ak nej! Analyserne stopper her og giver ikke svar på spørgsmål som: Hvad er det, der adskiller de norske unge fra de danske? 
Er de mere normløse, eller lever de i andre familiestrukturer? Og hvad kendetegner de mellemstore og store norske kommuner, hvor valgdeltagelsen især er faldet? Har de mange unge? Eller en stor indvandrebefolkning (jf. kapitel 11)? Jeg vil se frem til en bog om norske lokalvalg, der har et sådant undersøgelsesdesign, at den kan svare på, hvorfor valgdeltagelsen falder.

Annie Gaardsted Frandsen Institut for Pensions- og Ældrepolitik

Geoffrey Pridham, The Dynamics of Democratization. A Comparative Approach, London \& New York: Continuum, 2000, 330 s., \$95,00.

Godt 10 år efter at litteraturen om demokratisering oplevede en nærmest eksplosiv vækst, er det yderst kærkomment, at Geoffrey Pridham har sat sig for at skrive en bog med det formål at sammenfatte de mange bidrag til forståelse af drivkræfter bag, former for og konsekvenser af demokratiseringsprocesser. Pridham har i forvejen en række udgivelser om demokratisering bag sig, der mere specifikt har behandlet demokratiseringsprocesserne i Sydeuropa fra midten af 1970'erne og i Østeuropa efter 1989, ofte med fokus på den internationale dimension. Bogen her er det hidtil mest omfattende fors $\emptyset \mathrm{g}$ på en oversigt over den foreliggende - engelsksprogede - litteratur på området, og den vil derfor kunne gøre god fyldest som grundbog på seminarer og $\mathrm{i}$ anden undervisning om demokratisering.

Empirisk omhandler bogen Europa efter 1945, koncentreret om tre knudepunkter med hvert sit "sæt" af cases: 1) Tysklands og Italiens redemokratisering efter 2. verdenskrig, 2) Grækenlands, Portugals og Spaniens overgang til demokrati efter 1974 og 3) forandringsprocesserne i de østeuropæiske lande efter 1989. Bogen er komparativ, men ikke bygget op som casestudier. Den komparative tilgang udmøntes i sammenligninger over tid mellem de enkelte perioder og i sammenligninger i rum mellem erfaringerne i forskellige dele af Europa af udvalgte aspekter af demokratiseringsprocesserne.

I centrum for diskussionen står dog klart de udfordringer til demokratiseringsteori, som begivenhederne i Østeuropa udgør, og den nytænkning om den indbyggede dynamik i demokratiseringsprocesseme, der er opstået netop på baggrund af de østeuropæiske regimers sammenbrud, hvor demokratiseringen i snæver forstand har været ledsaget af andre dybtgående samfundsforandringer. Til forskel fra for eksempel tesen om en verdensomspændende "tredje demokratiseringsbølge", der omfatter alle demokratiseringsprocesser siden udviklingen i Sydeuropa tog fart i midten af 1970'erne, og forskellige "transitionsteoretikeres" tese om, at deres analysemodeller, der først og fremmest er udviklet på baggrund af cases i Latinamerika, også er anvendelige på Østeuropa, koncentrerer Pridham sig altså om europæiske erfaringer som grundlag for forståelse af udviklingen i Østeuropa i 1990'erne. En sådan bestræbelse må hilses velkommen. Forandringerne i Østeuropa i 1989, hvor det ene politiske system efter det andet pludseligt brød sammen, var nærmest helt uventede, udviklingens hastighed og de parallelle forløb i 
forskellige lande hidtil uset, og samtidigheden af forskellige processer med den deraf følgende kompleksitet oversteg klart tidligere erfaringer.

Demokratiseringsprocessemei Østeuropa er en del af en mere omfattende samfundsforandring, hvor der samtidig er tale om økonomisk liberalisering og nationbuilding-processer og i et vist omfang også state-formation-processer. Ud over selve demokratiseringsproblematikken er spørgsmålet om forholdet mellem demokrati og marked samt forholdet mellem demokrati og national identitet derfor også sat på dagsordenen i Østeuropa.

På denne baggrund opstiller Pridham sin egen interaktive eller dynamiske analysemodel (model of interactive dynamics), der netop skal tage højde for de aktuelle østeuropæiske flerdimensionelle forandringsprocesser (multiple trans. formations) og disses indbyrdes afhængighed. Det nævnes en passant, at samfundsvidenskabens opgave ikke kun er at beskrive, men at formulere forklaringsmodeller (explanatory models), men Pridhams egen analysemodel kan ikke siges at være en forklaringsmodel. Der er snarere blot tale om en analyseramme eller model over hvilke faktorer eller dimensioner, der skal indgå $\mathrm{i}$ analysen.

Modellen indeholder i alt otte dimensioner, der samtidig er strukturerende for bogens otte hovedkapitler. Det første behandler således spørgsmålet om historiske faktorer eller determinanter. Ud fra en antagelse om at demokratisering må forstås $i$ et diakront perspektiv, bliver det vigtigt at undersøge mulige effekter af en aktiv anvendelse af opfattelser af "arven" fra det tidligere autoritære regime såvel som udnyttelsen af eventuelle tidligere demokratiske traditioner. Det næste kapitel behandler det beslægtede spørgsmål om formen for det autoritære styres sammenbrud og betydningen heraf for demokratiseringsprocessen og mulighederne for en forankring af demokratiet.

En tredje dimension er den formelle regimetransition, ikke mindst de "konstitutionelle" aspekter heraf, og spørgsmålet om det institutionelle designs betydning for introduktionen af en retsstat, fremkomsten af et demokratisk regime samt udformningen af de demokratiske spilleregler. Pridham $g ø r$ her tydeligere end de fleste kendte demokratimålinger opmærksom på, at opfyldelse af de formelle kriterier ikke er tilstrækkeligt for eksistensen af et egentligt demokrati. Selvom de er "demokratisk" valgte, kan tidligere eliter fortsat dominere uden at være responsive eller repræsentative i forhold til vælgernes holdninger. I forlængelse heraf behandles forskellige aktørers modstand mod eller tilpasning til forandringen og deres rolle i legitimeringen af det demokratiske styre.

Den økonomiske transformation og demokratiseringen er genstand for et femte kapitel, hvor interaktionen mellem disse to processer er i centrum for diskussionen. Det galder både med hensyn til den samtidige $\emptyset$ konomiske transformations påvirkninger af regimeforandringen og med hensyn til det nye regimes $\varnothing$ konomiske politiks indflydelse på regimets legitimitet, som igen er af afgørende betydning for demokratiseringens videre udvikling. Eksempleme fra de tre "sæt" af demokratiseringer viser imidlertid ikke noget entydigt mønster.

En sjette dimension er spørgsmålet om civilsamfundets betydning for demokratiseringen, hvor det ikke mindst er relationen mellem elite og masse, der er til diskussion. Demæst behandles den nationale identitetsdannelse, herunder mulige 
etniske konflikter samt eventuelle statsdannelsesprocesser, der ledsager demokratiseringen, med henblik på at klarlægge, hvordan disse processer interagerer og påvirker demokratiseringen i gunstig eller ugunstig retning. I Østeuropa har de samtidige nation-building-processer hyppigt svækket demokratiseringen, mens det ikke har været tilfældet i de to andre sæt af demokratiseringsprocesser. Det sidste kapitel inden konklusionen behandler den internationale dimension af regimeformændringer med hensyn til, hvilken betydning mere direkte ekstern indflydelse og mere generelle udviklinger og begivenheder kan tillægges. Også her er der stor variation geografisk og tidsmæssigt både med hensyn til dybden og bredden af den internationale dimension.

Bogen er absolut anbefalelsesværdig, både som hjælp til at skabe overblik over litteraturen og som et - omend foreløbigt - bud på at etablere en model til forståelse af demokratiseringsprocesser i Europa i perioden efter 2. verdenskrig. På den måde er den en avanceret grundbog og ikke en ren introduktionsbog, fordi den forudsætter et vist kendskab til de seneste års debat om demokratiseringsprocesser. Ved siden af grundbogens styrke har den imidlertid også dens svagheder, idet de mange udførlige redegørelser og ikke mindst de mange forbehold over for entydige konklusioner, undertiden kan overskygge den røde tråd. Bogens hovedkonklusioner er derfor enten uklare eller gjort betingede. Der er for eksempel ikke noget eksplicit opgør med tesen om den altomfattende "tredje demokratiseringsbølge" eller tesen om transitionsteoriens universelle generaliserbarhed. Pridham er i sidste ende forsigtig med at udpege afgørende forskelle mellem Østeuropa og de tidligere eksempler på demokratiseringer, som han inddrager. På den ene side konkluderer han, at demokratiseringer generelt har været ledsaget af økonomiske ændringer og ændringer med hensyn til stat og/eller national identitet. Østeuropa er i dette perspektiv ikke speciel på grund af selve eksistensen af disse yderligere forandringsprocesser, men kun på grund af den relative betydning, de har fået $\mathrm{i}$ kraft af deres timing eller sekvensen i forhold til demokratiseringsprocessen, og udgør derfor ikke en særlig demokratiseringtype. På den anden side nævnes det gang på gang, at det er udviklingen i Østeuropa, der har sat samtidigheden af og interaktionen mellem disse processer på demokratiseringsforskningens dagsorden. Og det er da alligevel noget!

Uffe Jakobsen Institut for Statskundskab Københavns Universitet

Jørgen Dalberg-Larsen, Pragmatisk retsteori, København: Jurist- og Økonomforbundets Forlag, 2001, 200 s., kr. 263,00.

Med foreløbigt tredje bind i en serie om ret og retsteori under forandring foretager Jørgen Dalberg-Larsen med sin seneste bog et interessant greb tilbage i tiden. Hvor de to foregående bøger om henholdsvis retspluralisme (Rettens enhed - en illusion? Om retlig pluralisme $i$ teorien og i praksis fra 1994) og postmodeme rets- 
teori (Ret, tekst og kontekst. Postmodernisme og ret fra 1998) havde aktuelle retsteoretiske problemstillinger som omdrejningspunkt, baserer den seneste bog sig på et teorihistorisk tilbageblik på pragmatismens rødder og udvikling. Den historiske vægtning er dog ikke den eneste forskel fra de to tidligere bøger. Det er således iøjnefaldende, hvor meget Dalberg-Larsen denne gang markerer sin egen position, som han netop fremlæser gennem pragmatismen.

Et af bogens hovedærinder er ud fra pragmatismen at undersøge, hvilke fordringer man kan stille til retsvidenskaben i dag - et i sagens natur vanskeligt spørgsmål. Med vurderingen af kravene til retsvidenskaben vender bogen sig eksplicit mod den dogmatiske retsvidenskab, som udelukkende interesserer sig for at fastlægge gældende ret uden interesse for rettens almene samspil med det $\varnothing v$ rige samfund, herunder ikke mindst rettens virkninger. Det virker måske i sig selv overraskende, at det stadig kan være nødvendigt at opponere mod en sådan opfattelse af retsvidenskab, men det er faktisk tilfældet! Heroverfor argumenterer Dalberg-Larsen både pædagogisk og overbevisende - og med teoretisk udsyn - for et pragmatisk retssociologisk perspektiv, som fastholder, at den rent retsinterne (dogmatiske) tilgang må suppleres med eksterne betragtninger.

Dalberg-Larsen udleder sit eget pragmatiske program af en analyse først af pragmatismen som filosofisk retning (fra Peirce, James og Dewey til Rorty) og demæst af ældre og nyere positioner inden for pragmatisk retsteori (fra blandt andre Holmes og Pound til Posner og Tamanaha). Det, der for Dalberg-Larsen er centralt, er den pragmatiske af visning af metafysik (men installerer Posners rets$\emptyset$ konomi ikke en ny metafysik med begrebet om rationelle individer?) og abstrakt formalistisk teoridannelse, som i stedet fordres afløst dels af teoretiske bestræbelser på at kortlægge de almene konsekvenser af retlig regulering, dels af en indoptagelse af socio-legal studies til dette formål, dels af en sammenkædning af disse med værdimæssige og retspolitiske overvejelser og dels af en styrkelse af demokratiet; alt sammen midler til at komme hinsides den snævre retsdogmatik.

Den amerikanske inspiration sættes på interessant vis i forbindelse med den europæiske kontekst, hvor pragmatismen sammenholdes med den skandinaviske retsrealisme og med Habermas. Desuden modstilles pragmatismen Luhmann, som efter min opfattelse får en lidt stedmoderlig behandling. Luhmann kritiseres eksempelvis for at mene, at retten skulle være et lukket system, men læser man Luhmann, ser man hurtigt, at lukningsfiguren tjener som mulighedsbetingelse for åbning, og ikke mindst $\mathrm{i}$ hans analyser af retten fremhæves det gang på gang, at retten i høj grad evner at indoptage og omforme ekstralegale aspekter.

I stedet for at afskrive Luhmanns teori som abstrakt og virkelighedsfjem kunne den anvendes til at problematisere en af de antagelser, Dalberg-Larsen bygger sin argumentation på: at virkeligheden er en (objektiv, iagttageruafhængig?) størrelse "derude", som det gælder om at skabe en bedre kobling til teoretisk. Denne virkelighedsopfattelse kan ikke tages for givet, men må i højere grad diskuteres i lyset af blandt andet konstruktivistiske ansatser. Et relateret problem knytter sig til Dalberg-Larsens krav om at $\emptyset$ ge inddragelsen af konsekvensberegninger i den retlige regulering. Jeg er principielt enig i synspunktet, men mener ikke, at det er så enkelt, som der lægges op til. Dalberg-Larsens eget eksempel er kriminalpolitik, 
som efter hans mening bør grundes mindre på politikernes intuitive fornemmelser og mere på kriminologisk forskning. Problemet er imidlertid - og det er naturligvis ikke udelukkende et specifikt kriminologisk problem - at der hersker overordentlig stor usikkerhed om konsekvenserne af givne tiltag, hvad der mere generelt understreges af Ulrich Becks risikosamfundsdiagnose. Hvad skal man lade sig lede af $\mathrm{i}$ en sådan situation? Det oplagte svar er: pragmatiske afvejninger, men dermed ender man let i en virkelighedsfjern (!) blindgyde, som overser, at kriminalpolitik frem for alt er politik, og dermed styret af politiske interesser. Det ville for mig at se være mere pragmatisk at tage udgangspunkt i dén realitet og at udforme eventuelle ændringer på den baggrund.

Som antydet kunne man nogle gange ønske sig en mere indgående argumentation og diskussion i bogen, og det betyder, at ambitionen om at formulere de krav, man kan stille til retsvidenskaben, ikke helt indfris. Naturligvis kan man ikke inkludere alt $\mathbf{i}$ en fremstilling, som for en stor dels vedkommende samtidig fungerer som introduktion til et teoretisk perspektiv, og man kan derfor håbe på, at bogen også har karakter af et springbræt til et kommende opus, som mere udfoldet præsenterer Dalberg-Larsens egen position. Indtil da bør bogen dog være pligtlæsning for dogmatisk sindede jurister.

Christian Borch

Det retsvidenskabelige Institut $D$

Københavns Universitet

Anne Stevens with Handley Stevens, Brussels Bureaucrats? The Administration of the European Union, Houndmills: Palgrave, 2001, 277 s., £16,99.

De administrative aspekter af EU-projektet er fascinerende. Den logistiske udfordring i at få et samarbejde mellem 15 forskellige lande til at fungere i praksis er overvældende. Alle medlemslandene ankommer til Bruxelles med deres eget sprog og administrative kultur. Udvides EU med 10-12 nye medlemslande, bliver den administrative udfordring ikke just mindre. Der er også en anden grund til, at administration i EU er spændende. Santer-kommissionen måtte som bekendt i 1999 trække sig tilbage. Det skyldtes sønderlemmende kritik fra den uafhængige ekspertgruppe, hvis rapport om administrative svigt i Kommissionen Santer ikke kunne sidde overhørig. Et af Prodis første skridt som ny kommissionsformand var at lave en hvidbog om administrativ reform af Kommissionen. Administrationskommissær Neil Kinnock har netop i sommeren 2002 givet første status på reformarbejdet, hvis sigte blandt andet er at forbedre Kommissionens interne revisions- og kontrolsystemer. EU-projektet er kort sagt i rivende udvikling - også på det rent administrative område.

Problemet er, at EU's administration ikke hører til de mest velbelyste emner inden for den offentlige forvaltning. Det gælder ikke mindst på lærebogsplanet. Her fylder Brussels Bureaucrats? et hul. Forfatterne har lavet en solid og oplysende introduktion til EU's administration. De starter med at redegøre for histo- 
rien bag EU's administrative organisation, herunder hvilke nationale administrative modeller der har fungeret som forbilleder. Der lægges her særlig vægt på den franske og tyske arv. Herefter gennemgår forfatterne EU-administrationens reguleringsmæssige grundlag. EU's tjenestemandsvedtægt gennemgås, og medarbejdernes og personaleorganisationernes indflydelse diskuteres. Herefter følger et par kapitler med klassiske forvaltningsemner som rekruttering af embedsmænd og deres karrieremønstre i EU-administrationen. Bogen sluttes af med et par gode kapitler om henholdsvis koordinationsmekanismer og forholdet mellem politik og administration i EU-systemet. Koordination udgør en særlig udfordring i EU-systemet. Det skyldes dels systemets generelt fragmenterede karakter (for eksempel er den udøvende magt delt mellem Rådet, Kommissionen og medlemsstaterne), dels de særlige splittelser, der kan opstå internt i EU-institutionerne. Som eksempel kan nævnes Kommissionen, hvor splittelser kan opstå mellem de enkelte generaldirektorater, dels som følge af "almindelige" ressortstridigheder, dels som følge af kommissærernes forskellige nationale baggrund og partipolitiske tilhørsforhold. Bogen redegør både for intraorganisatoriske koordinationsmekanismer (som for eksempel kommissærernes kabinetter og EU-institutionernes generalsekretariater) og interorganisatorisk koordination (som for eksempel trialogen mellem de centrale EU-institutioner og komitologien mellem Rådet og Kommissionen).

Alt i alt har Stevens og Stevens skrevet en nyttig, oplysende og letlæst introduktion til offentlig forvaltning i EU-regi.

Jens Blom-Hansen Institut for Statskundskab

Aarhus Universitet

Georg Sørensen, Changes in Statehood. The Transformation of International Relations, New York: Palgrave, 2001, 226 s., £45,00.

"Skellet mellem international og intern politik er blevet stadig mere utydeligt". Det er et udsagn, som nye statskundskabsstuderende hurtigt møder, når de begynder på studiet. Selv om de fleste kurser ved politologiske studier stadig henregnes til enten den ene eller den anden af de to kasser, er det blevet en del af enhver politologistuderendes basisviden at kunne forklare, hvorfor skellet ikke er så klart som forudsat $\mathrm{i}$ blandt andet stillings- og afdelingsstrukturer. Blandt de forskellige tilgange til og teorier om international politik genfindes antagelsen om den internationale politiks særlige karakter tydeligst i neorealismen. Neorealismen bygger på den centrale betydning af magt i det internationale systems anarkistruktur, mens udgangspunktet for at forstå intern politik er legitim myndighedsudøvelse i enheder (stater), der i princippet er ensartede (like units). I et introduktionskursus i international politik er det altid en god ide at begynde med at udvikle og forklare neorealismens logik og teoribygning og derefter skridt for skridt pille det hele fra hinanden igen! 
Changes in Statehood er endnu et opgør med neorealismen og antagelsen om den internationale politiks særlige karakter. Men bogen er langt mere end det. Forholdet mellem international og intern - eller hjemlig (domestic) - politik analyseres og diskuteres ud fra en speciel og på flere måder inspirerende synsvinkel. Udgangspunktet er, at et lands centrale værdier som sikkerhed, frihed, orden, retfærdighed og velfærd har både internationale og interne aspekter, og ingen af værdierne kan reduceres til enten internationale eller interne. I stedet argumenteres for den analytiske relevans af både udefra-ind (outside-in) og indefra-ud (inside-out) perspektiver. Af bogens 12 kapitler anskuer kapitel 2-6 forholdet mellem de to politiksfærer outside-in, mens kapitel 7-10 anlægger et inside-out-perspektiv. Kapitel 11 vurderer analysens konsekvenser for de vigtigste teorier $\mathrm{i}$ international politik, mens kapitel 12 fremlægger nogle overvejelser om den videre teoriudvikling. Samlet set illustreres bogens struktur med et kontinuum international-intern-international (figur 1.2., p. 23).

Outside-in-kapitlerne præsenterer først nogle generelle teorier om faktorer, der trækker i retning af henholdsvis homogene og heterogene interne strukturer, hvorefter betydningen af politisk-militær magt, internationale normer og $\varnothing \mathrm{konomisk}$ magt diskuteres. I kapitel 6 fremlægges et hovedpunkt i analysen, nemlig skellet mellem tre idealtyper af stater: den moderne, den postkoloniale og den postmoderne. Kapitel 7 binder på en fiks måde analysen af internationale og interne politikaspekter sammen ved hjælp af sikkerhedsdilemmaet. Dette begreb blev anslået af den engelske forsker John Herz i begyndelsen af 1950'erne og præsenteret som et generelt træk ved international politik. I Changes in Statehood er det et centralt argument, at den klassiske udgave af sikkerhedsdilemmaet alene er baseret på forholdet mellem moderne stater, mens det er kvalitativt forskelligt, når det gælder både postkoloniale og postmoderne stater. Moderne stater er de industrialiserede lande i Vesteuropa og Nordamerika i de første år efter 2. verdenskrig, mens lande i Sydøstasien og Latinamerika nærmer sig denne type. Postkoloniale stater er udviklingslandene, mens de postmoderne først og fremmest er landene i EU. Ser man på de forskellige regioner, er det klart, at sikkerhedsdilemmaet ikke er et uforanderligt vilkår $\mathrm{i}$ international politik, men betinges af forskellige konfigurationer af interne og internationale forhold.

I mange postkoloniale stater - især Afrika syd for Sahara - er det politiske liv præget af anarki, mens forholdet mellem postmoderne stater karakteriseres af koordinerede sikkerhedsfællesskaber. I postkoloniale stater er der svage regeringsstrukturer baseret på tvang og voldelige konflikter snarere end retslige reguleringer, og der er ikke noget legitimt voldsmonopol. Identiteten er rettet mod det etniske og lokale niveau og understøttes ikke af offentlige serviceydelser baseret på gunstige $\varnothing$ konomiske vækstbetingelser. De centrale problemer ligger $\mathrm{i}$ interne politiske, økonomiske og etniske strukturer, og en analyse, der forudsætter det klassiske sikkerhedsdilemma, er uden mening.

I postmoderne stater i Europa er den politiske styring og identitet flyttet til flere niveauer, både supra- og subnationale. De nationale økonomier er suppleret med omfattende transnationale netværk. Det betyder, at sikkerhedsfællesskabet på det mellemstatslige niveau -dvs. at voldelige konflikter mellem de pågældende 
stater er utænkeligt - er blevet til et koordineret fællesskab. Det er dermed hverken sammensmeltet (amalgamated) eller pluralistisk i forn af selvstændige stater som forudsat i Karl Deutschs klassiske begrebsapparat. De centrale problemer er forbundet med betingelsen for skabelsen af effektive og legitime styringsmekanismer på de forskellige niveauer, og igen gælder det, at en analyse, der forudsætter det klassiske sikkerhedsdilemma, er uden mening.

I kapitel 10 diskuteres konsekvenserne for den suveræne stat i relation til de forskellige statstyper. Der skelnes mellem suverænitetens konstituerende og regulerende aspekter, hvor det første er noget absolut, mens sidstnævnte er noget relativt og foranderligt. Det påvises, hvorledes der udvikles modsætninger og spændinger mellem de forskellige aspekter af suveræniteten i de tre statstyper. På forholdsvis få sider (18) gives en usædvanlig fyldig, stofmættet og dybdeborende analyse af et højst besværligt og sammensat problem. Til sidst i kapitlet antydes nogle problemer, der bør indgå i fremtidig forskning. Spørgsmålene tages op igen og specificeres i bogens afsluttende kapitel.

Changes in Statehood er et særdeles kvalificeret og grundigt bidrag til litteraturen om international politik, og det vil få en central placering i faglige diskussioner om forholdet mellem statstyper og ændringer i internationale relationer. En af grundene er, at bogen lægger op til nogle spørgsmål, overvejelser og forskningsemner, som Georg Sørensen kun strejfer eller går let hen over. For eksempel kan man spørge, om den postmoderne statstype - stater der som de europæiske er villige til at indgå i et internationalt samarbejde, der også kan være supranationalt - angiver en fremtid, som højt udviklede industrisamfund uden for Europa også vil opleve? Sørensen er ikke klar på dette punkt, og han afviser klogeligt enhver determinisme (pp. 145-146). Samtidig siges, at den moderne statstype er i "a process of decline". Det er utvivlsomt rigtigt - men til fordel for den "post"-moderne?

Her er det nærliggende at tage USA som eksempel: Der er næppe nogen, som vil vove den hypotese, at USA er på vej mod en postmoderne politik med en positiv holdning til supranationalt samarbejde. Man kan også nævne NIC-landene i Sydøstasien, hvor denne samarbejdsform ikke findes og heller ikke synes på vej. Er det da kun landene i Europa, som er/bliver postmoderne? Hvis ja - hvad er da konsekvensen for teorier om postmoderne stater?

Således fører Georg Sørensens værdifulde tilgang og analyse til nye centrale spørgsmål.

Erik Beukel Dansk Udenrigspolitisk Institut (DUPI)

Robert Jackson, The Global Covenant: Human Conduct in a World of States, Oxford and New York: Oxford University Press, 2000, 464 s., $£ 35.00$ (hb).

Med termen the global covenant refererer Robert Jackson til den model for international orden, som ofte forbindes med den Westfalske Fred i 1648, nemlig et system af stater, som anerkender hinandens suverænitet, og som baserer deres 
relationer med hinanden på fundamentale institutioner som diplomati og international ret samt en række spilleregler for international politik så som staternes ejendomsret, ikke-interventionsprincippet og respekt for indgåede aftaler. Styrken ved dette historisk udviklede institutionelle arrangement er ifølge Jackson, at det forener hensynet til international orden med hensynet til staternes frihed, uafhængighed og forskellighed. Det er således denne globale pagt, som det moderne internationale samfund hviler på. Jacksons erklærede ambition er intet mindre end at udvikle, opdatere og forstærke teorien om dette internationale samfund, først og fremmest inden for rammerne af den engelske skole. Med The Global Covenant forsøger Jackson altså at skrive sig ind blandt klassikere som Hedley Bulls The Anarchical Society (1977), Martin Wights International Theory: The Three Traditions (1991) og Adam Watsons The Evolution of International Society (1992). Uanset hvad man mener om den konservative tendens i The Global Covenant, er det efter undertegnedes mening også i det selskab, bogen hører hjemme, for der er tale om en imponerende konsistent, sammenhængende og overdådig rig teori om det moderne internationale samfunds indretning, funktionsmåde og dilemmaer.

I bogens første del udfolder Jackson sin version af teorien om det internationale samfund og det videnskabsteoretiske grundlag herfor. Jacksons udgangspunkt er, at international politik er en humanistisk aktivitet, hvor staternes repræsentanter tager beslutninger med henvisning til, hvad der tjener staten, befolkningen, det internationale samfund og menneskeheden bedst, altså argumenter af en grundlæggende normativ karakter. Staterne, det internationale system og det internationale samfund er menneskeskabte konstruktioner, som opretholdes og styres af mennesker, og international politik er således en særlig afdeling af de humanistiske videnskaber. Der er fysiske realiteter, som lader sig observere, men der er ingen politisk realitet, som ikke afspejler menneskelig tænkning og handling, hvorfor fortolkning er nødvendig. Jackson afviser således den positivistiske tilgang til studiet af international politik inklusive eksponenter som Kenneth Waltz og Thomas Schelling, og kritisk teori og konstruktivismen går samme vej.

Tilbage står den klassiske humanistiske tilgang, som dominerede statskundskaben før den behavioralistiske revolution, og som baserede sig på historisk, juridisk og sociologisk fortolkning, politisk teori og komparativ politik, og hvis genstandsfelt blandt andet var politiske systemer, institutioner og sociale roller. Det kan diskuteres, om det er frugtbart af Jackson i den grad at insistere på et humanistisk videnskabeligt udgangspunkt i betragtning af, at samfundsvidenskabeme selv rummer fortolkende tilgange, som sætter fokus på aktørernes handlerum og intersubjektiv mening, og Jackson trækker da også på blandt andre Max Weber. Når det kommer til konkrete anvisninger på, hvordan den klassiske metode kan anvendes i praksis, er der imidlertid ingen tvivl om, at Jackson hæver sig op over de bidrag, der tidligere er fremkommet fra den engelske skoles side. Kapitlerne 3 og 4, og i særdeles siderne 92-96, kan således varmt anbefales til alle, som ønsker at anvende den klassiske fortolkende tilgang til studiet af international politik, og bogen som helhed tilbyder en solid teoretisk forankring herfor.

Inspireret af Hedley Bull og Martin Wight er Jacksons politiske teori om det internationale samfund for det første baseret på en sondring mellem konstitutive 
principper, regler og institutioner, såsom suverænitet, ikke-interventionsprincippet, diplomati og international ret, og så et såkaldt "hjælpeapparat" bestående af supplerende normsystemer og organisationer som for eksempel FN og den humanitære folkeret. For det andet sondrer han imellem to grundlæggende standarder for international optræden, nemlig dem, der har at gøre med internationale grundregler som for eksempel suverænitet, ikke-intervention og diplomatisk immunitet (procedure), og så dem, der har at gøre med behovet for at handle med formuft og forsigtighed i den konkrete situation (prudence). Forsigtighed og fornuft danner basis for eksempelvis alliancer, handel, international økonomi og andre former for instrumentelt samarbejde, mens procedurer danner basis for indgåelse af aftaler og overholdelse af regler og konventioner.

Bogen udmærker sig også ved en teoretisering af international etik og den udenrigspolitiske beslutningstagen. Udgangspunktet for denne er, at statslederne nok har et handlerum, men at de er nødt til at retfærdiggøre deres handlinger og begrunde deres valg såvel indadtil som udadtil. Statsmanden har således et ansvar for (1) sin egen befolknings sikkerhed, velfærd og velbefindende, (2) det internationale samfunds fundamentale regler og institutioner og dermed international orden, sikkerhed og fred, (3) andre landes borgere jf. den humanitære folkeret og (4) jorden som helhed, herunder miljøet. Filosofien bag det nationale ansvar er $\mathbf{i}$ høj grad forsigtighed og fornuft (prudence), og der er vel at mærke tale om en moralsk forpligtigelse, som forfølges under hensyntagen til international orden (procedure), og som derfor ikke skal forveksles med realisternes fokus på egoisme og egeninteresse. Jackson siger ikke meget om prioriteringen af disse hensyn eller dynamikken bag forandringer heri, men han peger dog på faktorer som den nationale og internationale offentlige opinion, prestige og konkrete omstændigheder.

The Global Covenant er et mesterværk, hvad angår teoretisk konsistens, analytisk rigdom og pædagogisk fremstilling, men som allerede antydet er bogen ikke hævet over kritik. Ved nærmere eftersyn er Jacksons globale pagt synonym med den såkaldt pluralistiske udgave af det moderne internationale samfund. Her er staten den absolut dominerende aktør og garanten for "det gode liv", mens det internationale maskineri af regler og institutioner først og fremmest underst $\emptyset$ tter en international orden, som giver den enkelte stat frihed til at indrette sig, som den vil. Jackson ser dette normative arrangement som tolerant og anti-paternalistisk, men hvad sker der med det internationale samfund, når staten ikke kan levere den vare, som er dens eksistensberettigelse, nemlig at være rammen om det gode liv? Hvad er det internationale samfunds svar på folkemord, forbrydelser mod menneskeheden, statssammenbrud og despoti?

Jacksons svar er en insisteren på de pluralistiske grundnormer. Dette fremgår dels af det afsluttende forsvar for det pluralistiske internationale samfund i bogens tredje del (de værdimæssige præmisser for dette forsvar er lagt frem fra bogens start), dels af bogens anden del, som behandler nogle udvalgte problemstillinger og praksisændringer i det internationale samfund, sådan som det har formet sig efter den kolde krigs oph $\emptyset$ r. Således ser han den genoplivede ret til humanitær intervention, relanceringen af internationale protektorater (jf. Kosovo og Øst-Timor), den større imødekommenhed over for krav om national selvbestemmelse og ikke 
mindst Vestens promovering af demokrati og menneskerettigheder som stærkt problematisk. Disse forandringer, som alle kan henføres til den såkaldt solidariske version af det internationale samfund, afvises på et stringent teoretisk grundlag, som ikke bør fejes til side uden nærmere eftertanke. For de fleste iagttagere er disse forandringer imidlertid enten $\emptyset$ nskelige eller nødvendige, og set $i$ lyset af den folkeretlige, institutionelle og politiske udvikling i det internationale samfund siden 2. Verdenskrig, og især efter Murens fald i 1989, fremstår Jacksons position trods sporadiske åbninger (pp. 173, 175, 201 og især 385) som konservativ og tilbageskuende på disse punkter.

Disse indvendinger rokker dog ikke ved de landvindinger, som er blevet påpeget ovenfor. Dertil kommer, at bogen tager højde for en god del af den kritik, som kan rettes imod den. Når det handler om internationale forandringer, som overskrider den klassiske pluralistiske model for det internationale samfund, dvs. staternes og statsledernes internationale samfund, tager Jackson i reglen det konservative standpunkt, men han gør det sjældent uden at fremlægge de tendenser og argumenter, som kunne tale for en alternativ position. Derfor er The Global Covenant en analytisk gave for både studenter og forskere, og det gælder for tilhængere såvel som modstandere af Jacksons pluralistiske position.

Tonny Brems Knudsen Institut for Statskundskab Aarhus Universitet 


\section{Modtagne bøger}

Andersen, Heine, Samfundsvidenskaber i kontekst, Frederiksberg: Samfundslitteratur, 2002.

Bauman, Zygmunt, Arbejde, forbrugerisme og de nye fattige, København: Hans Reitzels Forlag, 2002.

Beck, Ulrik, Fagre nye arbejdsverden, København: Hans Reitzels Forlag, 2002.

Brügger, Niels \& Orla Vigsø,Strukturalisme, København: Samfundslitteratur, 2002.

Christensen, Else \& Tine Egelund, Børnesager, evaluering af den forebyggende indsats, København: Socialforskningsinstituttet, 2002.

Egelund, Tine \& Signe Andrén Thomsen, Tarskler for anbringelse, København: Socialforskningsinstituttet, 2002.

Ejersbo, Niels \& Carsten Greve (red.), Den offentlige sektor på kontrakt, København: Børsens Forlag A/S, 2002.

Evald, Jens et al., Om retspolitik, København: Jurist- og Økonomforbundets Forlag, 2002.

Gilje, Nils \& Harald Grimen, Samfundsvidenskabernes forudsatninger, København: Hans Reitzels Forlag, 2002.

Gottlieb, Henning, Økonomiske konger, John Kenneth Galbraith, København: Jurist- og Økonomforbundets Forlag, 2002.

Green-Pedersen, Christoffer, The Politics of Justification, Amsterdam: Amsterdam University Press, 2002.

Hviid Jacobsen, Michael \& Søren Kristiansen, Erving Goffman, sociologien om det elementere livs sociale former, København: Hans Reitzels Forlag, 2002.

Jensen, Carsten, Jonas Jensen \& Thomas Jensen (red.), Nye vinde, nye veje. Udfordringer og visioner for Socialdemokraterne i en stormfuld tid, Frederiksberg: Samfundslitteratur, 2002.

Jørgensen, Torben Beck \& Kurt Klaudi Klausen, Territorial Dynamik, Århus: Aarhus Universitetsforlag, 2002.

Kjørup, Søren, Semiotik, København: Samfundslitteratur, 2002.

Olsen, Henning, Kvalitative kvaler, København: Akademisk, 2002.

Orrje, Helena \& Eskil Wadensjö, Immigration and the Public Sector in Denmark, Arhus: Aarhus Universitetsforlag, 2002.

Paldam, Martin, Udviklingen i Rusland, Polen, og Baltikum, Århus: Aarhus Universitetsforlag, 2002.

Rivers Pitt, William \& Scott Ritter, Krig mod Irak?, København: Forlaget Bindslev, 2002.

Sartre, Jean-Paul, Eksistentialisme er en humanisme, København: Hans Reitzels Forlag, 2002.

Sestoft, Christine, Med hensyn til den politiske forbruger, København: Akademisk, 2002.

Thompsen, John B., Den politiske skandale, København: Hans Reitzels Forlag, 2002. 


\section{Abstracts}

Vibeke Schou Pedersen

Paradoxes of Security: Terror, Threat and Tradition in American Foreign Policy

This article explores the dynamics between American modes of self-narration and patterns of foreign policy conduct. Pointing to the continual influence of the Puritan heritage and its notion of an exceptional American purpose, I join those who find American national identity a fabric articulated almost exclusively in what I choose to term a liberal and missionary vocabulary. In opposition to conventional assumptions, however, I depict exceptionalism and liberalism as highly contradictory ways of making - and making sense of - the world and America's place within it. Furthermore, I show how such contradictions have repeatedly defined a set of highly inflexible and ultimately destructive dilemmas in American foreign policy.

\section{Morten Ougaard}

\section{The American Mission In An Altered Global System}

A historicized theory of American foreign policy focuses on the American Mission as a teleological component founded in societal structures and political culture. The mission is to shape the external world in accordance with American interests and values, and it defines a line of continuity in foreign policy since the establishment of the republic. Globalization and the end of the cold war have created the possibility that domestic politics to a greater extent than before is manifested in the contents of foreign policy, but a review and comparison of selected statements and actions under the current and the previous administration indicate that although a right turn is discernible, the dominant characteristic is continuity understood as the adaptation of the American mission to a transformed world, especially after 9.11.

\section{Kenneth Mфller Johansen}

The Policy of Security: Clinton, Congress and the Strategic Missile Defense Struggle

With its focus on worst-case scenarios, the controversial Rumsfeld report enabled USA to recognize more, and more dangerous, missile threats, thus paving the way for legislation on strategic missile defense. Yet, recent contributions from critical security studies argue that threats are social consuructs. The article applies the Copenhagen School's securitization approach to analyze the political struggles that took place in Washington in the 1990s over the construction of a threat image that would justify missile defense. 


\section{Liselotte Odgaard \\ The War Against Terror and USA's Role in the International Community}

On the basis of the English school concepts of international society and legitimacy, the article argues that the terrorist attacks on the US in 2001 have placed the US terror strategies of the 1990s at the center of American security priorities. This change affects US interpretations of legitimate exertion of political authority towards individuals. In the 1990s, the US advocated that respect for human rights, democracy and the rule of law were to have a bearing on the rights and obligations of states. At present, this policy is shelved to the advantage of the effective control of political authorities over territory and population. In addition, the US prioritization of the fight against terrorism affects its relations to alliance partners. In the 1990s, the US made an effort to demonstrate loyalty towards and strengthen relations with old allies. By contrast, the US now demands their acceptance that the right to self-defense allows the US to use force against anyone suspected of participating in terrorist activities or of possessing weapons of mass destruction. This policy has engendered disagreements between the US and Europe and political dilemmas among US allies in the Middle East and Asia because of doubts that the US will continue to consider the common interests and rules of legitimacy in the international community.

\section{Rune Slothuus}

Designing Parties: Voter Strategies in the Social Democratic Party and the Liberal Party

Interviews with central strategists in the Liberal Party and the Social Democratic Party show that the parties are engaged in a continuous, targeted process between elections. The parties attempt to steer the political agenda towards issues they "own", and they explicitly consider which image will get the voters on their side. In the short term, the parties work intensely to control the media image so that it supports their more long-term image work. The parties are capable of learning from failed election campaigns and put great emphasis on winning credibility among the voters by securing a connection between political messages and actual results. 


\section{Om forfatterne}

Vibeke Schou Pedersen, ph.d.-studerende, Institut for Statskundskab, Københavns Universitet, finansieret af Center for Fred og Konfliktforskning (COPRI) med et projekt, der indgår i COPRIs forskningprogram "Global Governance" (GOV). Cand.scient.pol. fra Københavns Universitet, marts 2001, og som del af kandidatuddannelse Nordplus-fellow ved Idehistorisk Institut, Universitetet i Oslo. Oktober 2001 til oktober 2002 Marie Curie Fellow ved Department of International Politics, University of Wales, Aberystwyth. Hovedinteresser er amerikansk udenrigspolitik, amerikansk intellektuel historie, republikanisme, klassisk realisme og post-positivistisk etik. Har publiceret artikler om amerikansk udenrigspolitik, amerikansk nationalisme og om Richard Rortys pragmatisme i danske tidsskrifter. E-mail: VP@ifs.ku.dk

Morten Ougaard, dr.scient.pol., docent i international politisk $\emptyset$ konomi, Handelshøjskolen i København. Af nyere publikationer kan nævnes "Kursskifte eller kaos. Om Amerikansk Udenrigspolitik under George W. Bush", Militert Tidsskrift, nr. 4, 2002; Morten Ougaard and Richard Higgott (eds.), Towards a Global Polity, London \& New York: Routledge, 2002. E-mail: mo.ikl@cbs.dk

Kenneth Møller Johansen, Bachelor i Statskundskab, Aarhus Universitet, Master (Distinction) i Security Studies, University of Wales, Aberystwyth. Har skrevet kronikker om amerikansk udenrigs- og sikkerhedspolitik og har tidligere udgivet "Amerikansk udenrigspolitik og repræsentationen af fare" (med Terkel Kunding) i Politologiske Studier. Skriver netop nu speciale om kritisk sikkerhedsteori og flygtninge i nærområder på Institut for Statskundskab, Aarhus Universitet. E-mail: moeller_johansen@get2net.dk

Liselotte Odgaard, ph.d, lektor i international politik, Institut for Statskundskab, Aarhus Universitet. Har især arbejdet med sikkerhedspolitik i Sydøstasien og USA's udenrigspolitik. E-mail: lodgaard@ps.au.dk

Rune Slothuus, stud.scient.pol., Institut for Statskundskab, Aarhus Universitet. Særlig interesse for emner inden for politisk sociologi. Underviser i Politologisk Introduktionskursus ved Institut for Statskundskab. Praktikophold ved ugebrevet Mandag Morgen, foråret 2002. E-mail: runeslothuus@ @otmail.com 


\section{politica}

35. årgang indeholder følgende temaer og aktuelle enkeltartikler samt anmeldelser:

\section{USA som global aktør}

Vibeke Schou Pedersen: Sikkerhedsparadokset: terror, trusler og tradition

Morten Ougaard: Den amerikanske mission i et forandret globalt system

Kenneth Møller Johansen: Sikkerhedens politik: Clinton, Kongressen og kampen om missilforsvar Liselotte Odgaard: Krigen mod terror og USA's rolle i det internationale samfund

Rune Slothuus: Partier med omtanke

\section{Professioner i den offentlige sektor}

At der i stort omfang er ansat professionelle i den offentlige sektor er ikke nogen ny foreteelse. Fordelene og ulemperne ved at ansætte professionel arbejdskraft er intenst diskuteret i professionslitteraturen. Den funktionalistiske tradition, hvor de professionelle anses for at være drevet af et uegennyttigt kald, repræsenterer det ene yderpunkt. Den neo-weberianske rradition, hvor udgangspunktet er, at professionerne stræber efter at forøge egen status og magt, repræsenterer det andet yderpunkt. Temanummeret belyser fordelene og ulemperne ved professioner gennem en række analyser af forholdene i den danske offentlige sektor.

\section{Artikler uden fælles tema}

Redaktionen har besluttet at $\emptyset$ ge antallet af frie artikler, dvs. artikler, der ikke er bundet sammen af et fælles tema. Årgangens tredje nummer er planlagt til at indeholde $5 \mathrm{a} 6$ spændende artikler om hver sin politologiske problemstilling. Frem til 1. maj 2003 vil det være muligt at indsende artikelforslag til redaktionen med henblik på dette nummer. Desuden publicerer vi løbende $1 \mathrm{a} 2$ artikler uden for tema. Indsendte artikler bedømmes anonymt af to referees samt redaktionen. Manuskripter må ikke fylde over 7500 ord inklusive noter og litteraturliste og skrivesefter retningslinierne i Politicas skrivevejledning (www.ps.au.dk/politica).

\section{0 år efter jordskredsvalget}

Jordskredsvalget 4 . december 1973 rystede dansk politik. Med ét var det som om, den stabilitet, der hidtil havde kendetegnet dansk politik, var forsvundet. 30 år efter gør Politica status over udviklingen siden 1973. Vendte stabiliteten i partisystemet tilbage? Hvordan er det gået med de nye partier, der kom i Folketinget? Var vælgeradfærden ved jordskredsvalget et engangsfænomen, eller var det starten på en ny fase i vælgernes måde at opføre sig på?

$\begin{array}{ll}\text { Abonnementspriser for 35. årgang: } \\ \text { Studenterabonnement } & 210,00 \mathrm{kr} . \\ \text { Normalabonnement } & 295,00 \mathrm{kr} \\ \text { Institutionsabonnement } & 395,00 \mathrm{kr} \\ \text { Enkeltnummer } & 100,00 \mathrm{kr} .\end{array}$


Bestilling af abonnement eller enkeltnumre:

Indbetal beløbet på girokonto 5045193

Tidsskriftet Politica

c/o Institut for Statskundskab

Universitetsparken

8000 Århus C

eller pr.e-mail: Politica@ps.au.dk; telefon: 89421253

Efter bestilling kommer tidsskriftet automatisk med posten.

Husk tydelig afsenderadresse.

\section{4. årgang af politica kan stadig fås:}

\section{Den danske velfærdsstats muligheder og problemer}

Jørgen Goul Andersen: Velfærd uden skatter. Det danske velfærdsmirakel i 1990’erne

Torben M. Andersen: Internationalisering og velfærdssamfund

Peter Abrahamson og Anette Borchorst: EU - en udfordring for den danske velfærdsstat?

Anders Lindbom: Den svenska välfärdsstaten under 1990-talet. Vad kan Danmark lära av de svenska erfarenheterna?

Christoffer Green-Pedersen: Den danske velfærdsstat fra afgrundens rand til efterlønsreform. En oversigt.

Vibeke Normann Andersen og Kasper Møller Hansen: Deliberativt demokrati og den nationale folkehøring om euroen

Søren Risbjerg Thomsen: Tripelvalget 2001: Valgvind, meningsmålinger og valgkamp

\section{Artikler uden fælles tema}

Jens Peter Frølund Thomsen: Politisk magt og pluralisme

Morten Larsen: Fødevareministeriet: fra erhvervets forlængede arm til forbrugernes beskytter?

Anne Binderkrantz og Helle Carlsen: Når sammenholdet brydes: splittelser af partier i Danmark

Michael Baggesen Klitgaard: Når forandringer stabiliserer: skandinaviske velfærdsstatsreformer i 1990'erne

Lars Johannsen: Demokratiseringsteori: klynger af forklaringer

\section{Den tredje vej}

Lars Bo Kaspersen: Den tredje vej - et svar på det 21. århundredes udfordringer?

Stefan Hermann: Kompetenceudvikling og livslang læring som politik for den tredje vej

Lars Thorup Larsen: Staten, det er ikke mig

Jørn Loftager: Aktivering som (ny) velfærdspolitisk tredjevej

Mads Holm Iversen: Laksko og gummistøvler: Kampen mellem Udenrigsministeriet og Erhvervsministeriet om eksportfremmearbejdet

\section{Integration og institutioner i EU}

Jens Blom-Hansen og Jørgen Grønnegård Christensen: De institutionelle spilleregler i EU

Gitte Juul Johansen og Trine Nielsen: Fra Luxembourg til Amsterdam

Rie Odsbjerg Pedersen: Mellem konflikt og dynamik. En casestudie af arbejdstidsdirektivet

Mette Balle Sørensen: EU-kommissionen som entrepreneur i spillet om den internationale handelspolitik

Mette Scharling Pilgaard: Nice-traktaten: et spørgsmål om kontrol? En analyse af EU-aktørers institutionelle valg forud for Nice-topmødet 2000

Anders Wivel: Realismen efter Waltz. udvikling eller afvikling? 


\section{Politicas ph.d.-serie}

Thomas Pallesen, Health Care Reforms in Britain and Denmark: The Politics of Economic Success and Failure, 1997, kr. 125,00.

Asbjørn Sonne Nørgaard, The Politics of Institutional Control: Corporatism in Danish Occupational Safety and Health Regulation \& Unemployment Insurance, 1870-1995, 1997, kr. 125,00.

Lars Dahl Pedersen, The Politics of Cost Containment in Public Services. Hospital Budgeting in Denmark, Germany, and the Netherlands, 1978-92, 1997, kr. 125,00 .

Jens Bejer Damgaard, Styring og effektivitet: Organisering af dansk børnepasning, 1998, kr. 125,00.

Iben Nathan, When Poor People Participate. A Case Study of a Local Government Election in a Locality of Rural Bangladesh, 1998, kr. 125,00.

Jens Blom-Hansen, Studier i statens styring af den kommunale sektors фkonomi, 1998, kr. 50,00.

Aksel Vladimir Carlsen, Socialdemokratismens muligheder og begransninger $i$ det postsovjetiske Rusland, 1999, kr. 125,00.

Hanne Marlene Dahl, Fra kitler til eget tøj-Diskurser om professionalisme, omsorg og køn, 2000, kr. 125,00.

Lars Johannsen, The Constitution and Democracy: The Choice and Consequence of the Constitution in Post-Communist Countries, 2000, kr. 125,00.

Mette Kjær, The Politics of Civil Service Reform: A Comparative Analysis of Uganda and Tanzania in the 1990s, 2001, kr. 125,00.

Bernhard Hansen, Party Activism in Denmark. A Micro Level Approach to a CrossSectional Analysis of the Correlates of Party Activism, 2002, kr. 125,00.

Vibeke Lehman Nielsen, Dialogens pris. Uformelle spilleregler, ressourcesymmetri og forskelsbehandling $i$ offentligt tilsyn, 2002, kr. 125,00. 




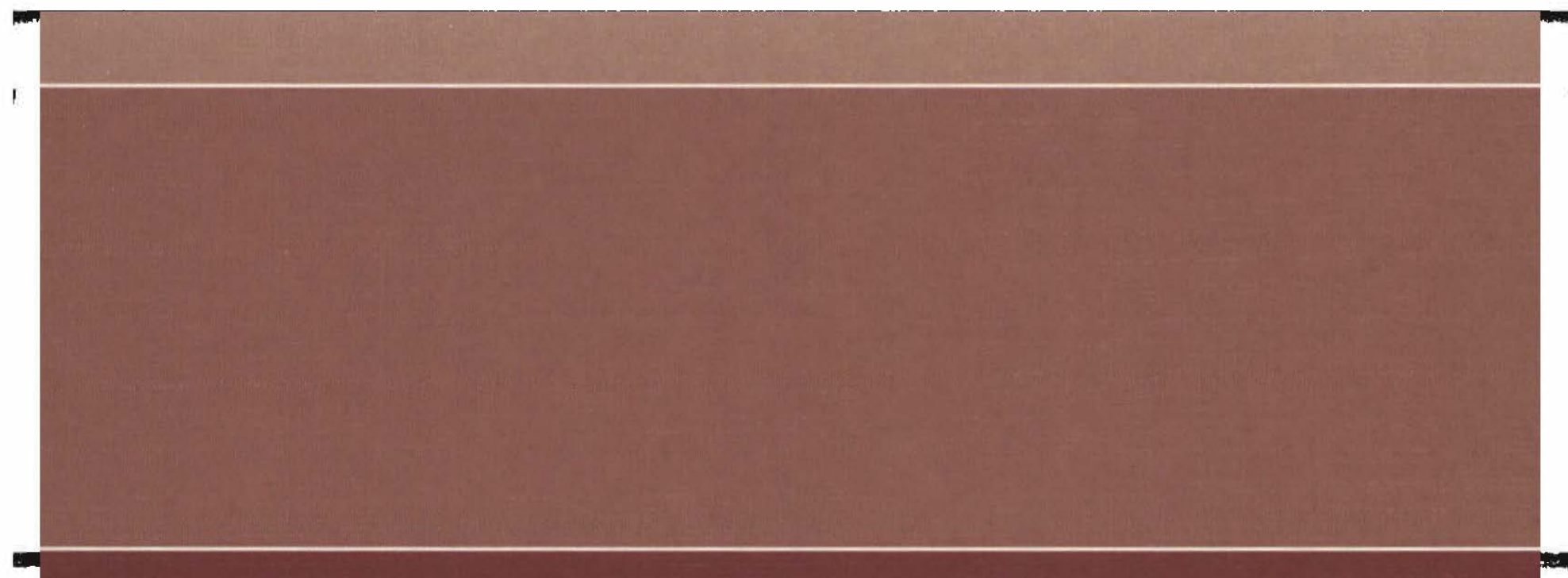

